\title{
KELUARGA SADAR GIZI (KADARZI) DALAM MENUJU GIZI BAIK UNTUK SEMUA
}

\author{
Abas Basuni Jahari ${ }^{1}$ \\ ${ }^{1}$ Puslitbang gizi dan Makanan, Depkes RI
}

\section{ABSTRACT \\ FAMILY NUTRITION AWARENESS TO ACHIEVE BETTER NUTRITIONAL STATUS FOR ALL}

Effort to improve nutritional status of the people in the last 20 year had been successfully achieved. The prevalence of Protein-Energy Malnutrition (PEM) decreased from 37.5\% in 1989 to $27.5 \%$ in 2003. The prevalence of lodine Deficiency Diseases (IDD) decreased from $27.9 \%$ in 1990 to $11.10 \%$ in 2003. The number of pregnant mothers with anemia and vitamin A deficiency were also decreasing. No sufficient data on other micronutrients status in Indonesia. Nutrition problem in Indonesia in general is still considered as a public health problem. Nutrition program in Indonesia has not been optimally involving nutrition education activities. In addition, the existing potential resources and sociocultural values in the community have not been taken into account in the implementation of nutrition program. Based on these past experiences, the Ministry of Health will focused its nutrition program to achieve Nutrition Awareness of all families (Keluarga Sadar Gizi, KADARZI) in order to reach to the improvement of nutritional status of the people. Nutritionally aware families are the families that able to know and overcome their own nutrition problem or to find aid from others to solve the problem. Following the development in new paradigm of nutrition program to achieve KADARZI, therefore the nutrition research activities should also in part focused on the development of nutrition education tools based on Communicator, Information, Education (CIE) Technics and Sociocultural aspects in the community.

Key words: Family Nutrition Awareness (KADARZI), Communication-Information-Education (CIE)

\section{PENDAHULUAN}

S ejak tahun 1980 Indonesia telah menunjukkan perbaikan gizi meskipun dengan kecepatan penurunan prevalensi kurang gizi yang lambat. Walaupun demikian, saat ini diperkirakan lebih dari 100 juta (lebih dari 50 persen) penduduk Indonesia masih menderita berbagai jenis kekurangan gizi. Demikian pula halnya dengan masalah gizi Kurang Energi Protein (KEP) pada anak balita di mana selama 5 tahun terakhir sejak tahun 1999 sampai 2004 tidak banyak mengalami perubahan.

Prevalensi kurang gizi lainnya, seperti berat badan lahir rendah (BBLR), anak balita pendek (stunted), gizi kurang (underweight), anemia, dan gangguan akibat kurang yodium (GAKY) masih tinggi. Masalah gizi di Indonesia menjadi semakin kompleks dengan meningkatnya masalah kegemukan pada anak-anak dan meningkatnya insiden Penyakit Kardio Vaskuler (PKV) pada orang dewasa yang berkaitan dengan masalah gizi lebih.

\section{MASALAH GIZI DI INDONESIA}

\author{
Masalah Gizi pada Anak Balita \\ Masalah KEP \\ Masalah KEP, yang ditunjukkan dengan \\ prevalensi anak usia di bawah 5 tahun \\ (balita) yang 'kurang berat' atau underweight
}


(<-2SD baku WHO) menurun selama 14 tahun terakhir, yakni dari 37,5 persen pada tahun 1989 menjadi 29,5 persen pada tahun 1998, dengan kecepatan penurunan ratarata per tahun 0,8 persen. Namun, penurunan masalah KEP tidak konsisten; sejak tahun 1999 hingga 2003 prevalensi gizi kurang naik dan turun 26-27 persen. Bila masalah KEP ini dipilah lagi menjadi gizi kurang (moderate underweight) dan gizi buruk (severe underweight), maka terlihat bahwa prevalensi gizi buruk pada tahun 2003 masih lebih tinggi dari keadaan pada tahun 1989.

\section{Masalah BBLR}

Masalah BBLR masih cukup tinggi di negara-negara sedang berkembang. Keadaan gizi dan kesehatan ibu merupakan faktor utama penyebab BBLR. Survei Demografi dan Kesehatan Indonesia 1997, yang merujuk periode 5 tahun ke belakang, menunjukkan bahwa pada tahun 19921997 prevalensi BBLR di provinsi-provinsi di Indonesia berkisar antara 3,6 dan 15,6 persen, dengan rata-rata nasional 7,7 persen. ${ }^{(1)}$ Keadaan ini tidak berubah banyak dari SDKI 1991 (7,3 persen) dan tahun 1994 (7,1 persen). Masalah BBLR berkaitan erat dengan terhambatnya pertumbuhan dan perkembangan anak, serta keadaan kesehatan yang kurang baik dan meningkatnya risiko kematian anak balita.

\section{Masalah Tinggi Badan}

Prevalensi anak balita pendek (stunted) menunjukkan tidak ada perubahan yang berarti dan cenderung meningkat. Pada tahun 1990 prevalensi anak balita pendek sebesar 44,5 persen $^{(2)}$ dan pada tahun 1992 turun menjadi 41,4 persen, ${ }^{(3)}$ tetapi kemudian meningkat kembali menjadi 45,9 persen pada tahun 1995 dan pada tahun 2001 sebesar 45,1 persen $^{(4)}$ Tingginya prevalensi gizi kurang (underweight), anak balita pendek, anak balita kurus menunjukkan bahwa masalah gizi pada anak balita sudah merupakan masalah yang serius.

\section{Masalah Berat Badan Kurus \\ Sebagaimana halnya dengan masalah anak balita pendek, prevalensi anak balita kurus juga cenderung meningkat. Menurut hasil SUVITA, ${ }^{(3)}$ prevalensi anak balita kurus pada tahun 1992 sebesar 8,6 persen yang meningkat menjadi 13,4 persen pada tahun 1995 dan 15,8 persen pada tahun 2001. ${ }^{(4)}$ Keadaan ini sudah diklarifikasikan sebagai masalah gizi yang serius.}

\section{Masalah Gizi pada Orang Dewasa Masalah KEK \\ Masalah kurang energi kronik (KEK) pada ibu-ibu merupakan indikator masalah gizi dan kesehatan di kalangan ibu-ibu yang memiliki risiko BBLR dan gangguan tumbuh- kembang pada anak sesudah lahir. Masalah gizi pada laki-laki dewasa juga memiliki risiko yang berimplikasi pada keadaan kesehatan secara umum serta pada menurunnya produktivitas kerja. \\ Secara umum masalah KEK (Indeks Massa Tubuh < 18,5) pada kelompok ibu adalah tinggi pada usia 15-19 tahun. Pada usia ini prevalensi KEK 2-3 kali lebih besar dari kelompok usia 40—44 tahun (Tabel 1).}

Tabel 1

Proporsi Wanita Usia Subur (WUS) dengan LILA $<23,5$ Menurut Umur

\begin{tabular}{|c|c|c|c|}
\hline Kelompok Umur & 1999 & 2000 & 2001 \\
\hline 15-19 thn & 41,6 & 38,0 & 40,8 \\
20-24 thn & 31,1 & 26,5 & 27,5 \\
25-29 thn & 25,8 & 19,0 & 19,1 \\
30-34 thn & 23,3 & 15,1 & 14,5 \\
35-39 thn & 19,7 & 14,0 & 12,9 \\
40-44 thn & n.a. & n.a. & n.a.
\end{tabular}




\begin{tabular}{|c|c|c|c|}
\hline $45-49$ thn & 25,1 & 13,1 & 13,1 \\
\hline
\end{tabular}

Source: BPS Statistics (2003); n.a. = tak ada data

Pola yang mirip juga ditemukan pada laki-laki, tetapi prevalensi yang tinggi $(40,8 \%)$ sudah terlihat pada kelompok umur 15-19 tahun. Indeks Massa Tubuh (IMT) kelompok lanjut usia menurun pada tahun pertama krisis dengan kenaikan proporsi IMT $<18,5$ yang signifikan. ${ }^{(5)}$

\section{Masalah Berat Lebih dan Kegemukan}

Jumlah orang dewasa yang memiliki berat lebih atau gemuk sudah relatif tinggi. di antara perempuan yang tidak hamil dan berumur 40-59 tahun, prevalensi berat lebih dan gemuk adalah 30 persen pada tahun 1997 dan 37,6 persen pada tahun 2000. Pada periode yang sama, prevalensi berat lebih dan gemuk pada laki-laki di kelompok usia ini lebih rendah dari perempuan, yaitu 14,9-17,9 persen. Kecenderungan dalam hal berat lebih dan gemuk adalah mirip dengan yang terjadi di banyak negara, baik berkembang maupun industri. Di negaranegara berkembang prevalensi berat lebih dan gemuk meningkat seiring dengan meningkatnya penyakit yang berkaitan dengan masalah kegemukan, seperti diabetes, penyakit jantung koroner, dan hipertensi. Prevalensi berat lebih dan gemuk di kalangan lanjut usia jauh lebih rendah. Pada kelompok usia lebih tua dari 60 tahun memiliki prevalensi 17,1 persen pada lakilaki dan 7 persen pada perempuan.

\section{Masalah Kurang Vitamin A (KVA)}

Indonesia merupakan satu negara berkembang yang pertama yang berhasil mengidentifikasi tingginya masalah KVA tingkat berat (xeroftalmia) sebagai masalah kesehatan masyarakat yang serius dan mulai melaksanakan program untuk memberantas masalah ini sejak tahun 1970. Pada tahun 1992, Indonesia berhasil menurunkan besarnya masalah KVA tingkat berat pada tingkat yang bukan lagi merupakan masalah kesehatan masyarakat. Namun, KVA masih dianggap sebagai masalah karena sebanyak 50 persen anak balita memiliki kadar retinol dalam serum $<20 \mu \mathrm{g} / \mathrm{dl}$. Suplemen vitamin A dosis tinggi untuk anak 6-59 bulan dan ibu nifas telah diimplementasikan untuk mencegah anak-anak dari kemungkinan menderita KVA tingkat berat.

\section{Masalah Anemia Gizi Besi (AGB)}

Informasi yang tersedia tentang masalah AGB berdasarkan hasil Survei Kesehatan Rumah Tangga (SKRT) Nasional tahun 1995 dan 2001 menunjukkan bahwa prevalensi AGB pada ibu hamil menurun dari 50,9 persen pada 1995 menjadi 40 persen pada tahun 2001.

Demikian pula halnya dengan prevalensi pada perempuan umur 15-44 tahun dari 39,5 persen pada tahun 1995 menjadi 27,9 persen pada tahun 2001. Namun, prevalensi AGB pada anak balita menunjukkan peningkatan dari 40 persen pada tahun 1995 menjadi 48,1 persen pada tahun 2001, terutama sangat tinggi pada anak balita umur di bawah 24 bulan, yakni sebanyak 55 persen.

\section{Masalah GAKI}

Prevalensi GAKI secara umum menunjukkan penurunan dari 27,9 persen pada tahun 1990 menjadi 11,1 persen pada tahun 2003. Laporan survei evaluasi GAKI 2003 menunjukkan, masih ada beberapa wilayah dengan prevalensi GAKI tinggi, di mana distribusi garam beryodium sulit menjangkau wilayah-wilayah tersebut. ${ }^{(6)}$ Hasil evaluasi program IP-GAKI 2003 menunjukkan bahwa 50 dari 146 kabupaten/ kota yang sebelumnya berstatus endemi berat membaik statusnya. Sebaliknya, 68 dari 254 kabupaten/kota yang berstatus nonendemi atau endemi ringan/sedang memburuk statusnya pada tahun 2003.

\section{Masalah Kekurangan Zat Gizi Mikro Lain \\ Risiko tinggi memiliki bayi dengan kelainan kongenital telah dideteksi di antara ibu-ibu hamil yang kurang gizi atau yang mengalami kekurangan zat gizi mikro. Kekurangan zat seng (zinc) pada ibu hamil diperkirakan berakibat pada tingginya risiko}


komplikasi kehamilan dan risiko bibir sumbing dan "palate deformities" pada bayi yang dilahirkan. Hasil penelitian di NTT (1996) menunjukkan, sekitar 71 persen ibu hamil menderita defisiensi zat seng dalam serum $(<7 \mu \mathrm{g} / \mathrm{dl})$. Studi lain di Jawa Tengah pada tahun 1999 oleh Satoto juga menunjukkan, prevalensi defisiensi zat seng pada ibu hamil tinggi, yaitu antara 70 dan 90 persen. ${ }^{(7)}$ Penelitian skala kecil lainnya di Jawa Barat, Jawa Tengah dan Lombok (1997-1999) menunjukkan, prevalensi defisiensi zat seng pada bayi sekitar 6 hingga 39 persen.(8) Besarnya masalah defisiensi zat gizi mikro lainnya, seperti asam folat, selenium, kalsium, vitamin $\mathrm{C}$, dan vitamin $B_{1}$ sampai kini belum diketahui.

Masalah gizi masih dianggap sebagai akibat kurang makan dan masih dianggap oleh banyak pihak sebagai masalah kesehatan. Anggapan yang kurang tepat ini berakibat pada lemahnya kebijakan dan program.

\section{FAKTOR-FAKTOR YANG TERKAIT DENGAN MASALAH KURANG GIZI}

Secara umum berbagai faktor yang dapat mengakibatkan terjadinya masalah gizi bukanlah masalah yang sederhana untuk memecahkannya, tetapi sangat kompleks. Bukan hanya penyebab langsungnya saja yang harus diperhatikan, penyebab tidak langsungnya atau akar masalahnya pun perlu mendapat perhatian.

\section{Faktor Sosial-Ekonomi}

Sudah diketahui secara luas bahwa penyebab KEP pada anak balita pada dasarnya adalah tidak tercukupinya pangan, adanya penyakit infeksi, adanya praktik pengasuhan dan perawatan anak yang kurang baik, atau kombinasi dari keadaankeadaan tersebut. Faktor lain, seperti pendapatan, keadaan lingkungan, pendidikan ibu, berpengaruh terhadap keadaan gizi anak balita melalui perubahan kuantitas dan kualitas makanan, penyakit, dan pengasuhan. Namun, pengaruh dari masingmasing faktor dapat berbeda pada lokasi yang berlainan.

Analisis data SUSENAS 2002 pada tingkat rumahtangga menunjukkan bahwa determinan utama dari masalah gizi kurang pada anak balita adalah pendidikan ibu, pengeluaran rumahtangga, penolong kelahiran (dukun tradisional atau tenaga medis/paramedis). ${ }^{(9)}$ Analisis data SUSENAS 2002 pada tingkat kabupaten/kota menunjukkan, pola yang serupa dalam hal faktor-faktor yang berkaitan dengan prevalensi gizi kurang pada anak balita. Akan tetapi, keragaman informasi di tingkat kabupaten/kota ini memberi implikasi penting pada kebijakan program perbaikan gizi. Implikasi dari keadaan ini adalah bahwa kebijakan yang efektif di satu kabupaten/kota belum tentu efektif untuk diterapkan di daerah lain bila tidak mengacu pada penanganan faktor kunci yang ada di daerah bersangkutan.

\section{Kemiskinan}

Dampak dari krisis ekonomi menunjukkan bahwa apa yang telah dicapai sejak tahun 1970 menjadi rawan dan mudah menurun. Analisis Suryahadi dkk (2001) berdasarkan data SUSENAS dan PODES ${ }^{1}$ menunjukkan bahwa jumlah rumahtangga yang rawan miskin meningkat hampir tiga kali dari keadaan sebelum periode krisis, dengan banyak peningkatan sebagai akibat meningkatnya kemiskinan kronis. Jumlah kemiskinan yang aktual berbeda signifikan antar-provinsi. Pada tahun 1999 jumlah penduduk miskin berkisar antara 6,2 persen di Jakarta hingga 60,4 persen di NTT; persentase peningkatan dari tahun 1996 ke 1999 berkisar antara 2,1 persen di Riau sampai 19,3 persen di Sulawesi Tengah. Kelompok masyarakat yang paling terpengaruh adalah di desa, terbanyak adalah yang kepala keluarganya bekerja pada sektor pertanian, dan sebagian besar dari mereka berpendidikan tidak tamat SD. Tidak ada perbedaan keadaan pada rumahtangga yang dikepalai laki-laki dengan yang dikepalai perempuan. Tingkat kemiskinan kembali ke keadaan sebelum 
krisis pada akhir tahun 1999. Survei yang dilakukan oleh $\mathrm{HKI}$ menunjukkan bahwa ada akibat terhadap keadaan gizi, terutama dalam perubahan pola makanan di beberapa kelompok masyarakat, misalnya berubah ke konsumsi telur atau makanan murah, dan meningkatnya anemia.

\section{Praktik Pemberian Makanan pada Anak}

Makanan dan status gizi ibu sebelum dan selama kehamilan berpengaruh pada pertumbuhan janin dan panjang bayi saat lahir. Suatu studi oleh Schmidt dkk (2002) di Jawa Barat menunjukkan bahwa ukuran bayi, terutama panjang badan bayi baru lahir, merupakan penentu paling penting terhadap pertumbuhan bayi sampai usia 1 tahun. Pola pertumbuhan anak Indonesia hasil SUSENAS menunjukkan bahwa gangguan pertumbuhan muncul pada usia sangat dini. Ini menegaskan bahwa keadaan gizi ibu dan praktik pemberian makanan merupakan penyebab utama gizi kurang.

Selama satu dekade terakhir belum terlihat adanya peningkatan praktik pemberian ASI eksklusif, pemberian ASI yang berkelanjutan, atau pemberian MP-ASI yang baik. ${ }^{(10)}$ Hasil analisis pendahuluan dari data SUSENAS 2002 menunjukkan bahwa hanya 40 persen anak balita usia kurang dari 4 bulan yang diberi ASI secara eksklusif. ${ }^{(9)}$ Tidak terdapat perbedaan praktik pemberian ASI eksklusif antara desa dan kota. Bertolak belakang dengan keadaan ini, sekitar 80 persen anak umur 6-9 bulan sudah diberi MP-ASI di samping masih terus disusui. Tampaknya, tingginya tingkat inisiasi pemberian ASI dibarengi dengan tingginya tingkat pengenalan dini makanan non-ASI.

Hasil survei Multi-site Complementary Feeding menunjukkan bahwa jumlah bayi yang diberi makanan formula bayi masih cukup tinggi, yaitu berkisar antara 9 persen di Belu, NTT, dan 41 persen di Barru, Sulsel. Hasil studi UGM menunjukkan bahwa bayibayi di Purworejo hanya memperoleh 225 kcal yang berasal dari MP-ASI yang dibuat ibunya dari 450 kcal yang dibutuhkan. ${ }^{(11)}$ Studi ini juga menunjukkan defisiensi zat gizi mikro pada MP-ASI yang diberikan, asupan (intake) zat besi dan seng kurang dari 30 persen Angka Kecukupan Gizi (AKG), dan asupan vitamin A kurang dari 50 persen AKG. Namun, asupan protein dinilai cukup.

\section{Morbiditas Anak Balita}

Tidak banyak data untuk mempelajari kecenderungan (trend) pada angka diare dan infeksi saluran pernapasan akut (ISPA) yang merupakan dua penyakit teratas yang banyak diderita anak. Terjangkaunya sumber air bersih dan kebersihan lingkungan merupakan pula determinan kunci masalah KEP. Pada tahun 2002, jumlah rumahtangga dengan akses ke air bersih meningkat sedikit selama 1 dekade terakhir, yakni sekitar 90 persen rumahtangga di kota dan 70 persen rumahtangga di desa. Jumlah rumahtangga yang akses ke jamban dan memiliki pembuangan air limbah ke septic-tank meningkat lebih dari dua kali dalam tahun ini. Namun, secara nasional sepertiga dari rumahtangga masih belum memiliki akses terhadap jamban ini.

\section{FAKTOR-FAKTOR LAIN YANG TERKAIT DENGAN MASALAH KURANG GIZI}

Partisipasi masyarakat dalam upaya perbaikan gizi melalui Pos Pelayanan Terpadu (Posyandu) secara umum masih rendah. Saat ini dari sekitar 240.000 Posyandu, hanya separuhnya yang masih aktif. Rata-rata kunjungan membawa anak balita untuk ditimbang di Posyandu sekitar 40 persen (berkisar 30-70\%). Kegiatan di Posyandu yang umum berjalan saat ini adalah kegiatan penimbangan bulanan. Akan tetapi, sebagian besar Posyandu tidak melaksanakan kegiatan konseling gizi sebagai bagian dari kegiatan penimbangan tersebut.

Belum ada data skala besar tentang keadaan Posyandu, tetapi beberapa studi skala kecil tentang Posyandu telah dilakukan. Penelitian di 2 kabupaten di Riau menunjukkan bahwa tingkat pengetahuan kader tentang arti grafik berat badan anak dalam KMS masih rendah, hanya 9 persen kader yang tahu tentang arti grafik KMS. Sebagian besar kader (98\%) tidak 
memahami pesan yang harus disampaikan sehubungan dengan perubahan berat badan anak balita. Dari penelitian di Riau ini juga ditemukan bahwa hanya 18 persen ibu dari anak balita yang memahami arti grafik dalam KMS. Survei yang dilakukan Direktorat Gizi Masyarakat ${ }^{(20)}$ menunjukkan, hanya sekitar 40 persen ibu dari anak balita yang memahami arti grafik pertumbuhan dalam KMS.

Kemampuan teknis kader Posyandu juga masih kurang. Dari penelitian tentang Posyandu di 4 Kabupaten, yakni Sukabumi, Bogor, Demak dan Semarang ditemukan bahwa kader yang mampu melakukan penimbangan dengan akurat hanya 3 persen dan yang memperoleh pembinaan dengan baik hanya sekitar 14 persen.

Beberapa hasil studi di atas menunjukkan bahwa upaya pemberdayaan masyarakat dalam upaya perbaikan gizi masih belum optimal. Faktor sosial-budaya masyarakat merupakan faktor penting lain yang perlu diperhatikan dalam upaya perbaikan gizi di masyarakat. Saat ini upaya perbaikan gizi masyarakat masih belum banyak menyentuh faktor sosial-budaya yang sangat bervariasi di masyarakat.

\section{BAHASAN}

Salah satu paradigma pembangunan bidang kesehatan adalah meningkatkan pemberdayaan masyarakat dalam upaya kesehatan. Di sisi lain paradigma upaya perbaikan gizi masyarakat ke depan akan ditujukan untuk menciptakan keluarga sadar gizi (KADARZI) sebagai jembatan antara untuk meningkatkan keadaan gizi masyarakat.

Pelaksanaan program gizi dalam upaya perbaikan gizi masyarakat masih lebih bersifat dengan pemberian intervensi (PMT, MP-ASI, pil besi, kapsul vitamin A dsb) kepada sasaran. Pada umumnya setiap intervensi yang dilakukan masih belum menyertakan pendidikan/penyuluhan gizi. Sebagai konsekuensinya, pemahaman masyarakat tentang pentingnya gizi bagi kesehatan masih rendah dan berakibat lebih lanjut pada sulitnya mempertahankan upaya perbaikan gizi yang berkelanjutan (sustainable). Dalam hal ini masyarakat akan sangat tergantung pada keberadaan program gizi untuk memperoleh zat gizi yang diperlukan, kemandirian masyarakat kurang untuk berusaha memperoleh zat gizi yang diperlukan.

Masalah gizi bukanlah masalah yang pemecahannya sederhana, tetapi sangat kompleks karena faktor penyebabnya sangat kompleks. Oleh karena itu, untuk penanggulangan masalah gizi perlu koordinasi berbagai sektor terkait dengan melibatkan berbagai potensi dalam masyarakat. Koordinasi antarsektor terkait ini masih menjadi masalah yang tidak kecil. Masih sering terdengar bahwa masalah gizi adalah tanggung jawab sektor kesehatan merupakan indikasi belum dipahaminya penyebab timbulnya masalah gizi secara utuh, baik di kalangan masyarakat maupun pelaksana program. Oleh karena itu, penanggulangan masalah gizi masih banyak yang bersifat penanggulangan terhadap penyebab langsungnya, yakni kurangnya asupan zat gizi dan penyakit infeksi. Penanggulangan terhadap akar masalah penyebab masalah gizi masih belum terintegrasi dengan baik atau masih bersifat sektoral.

Upaya mewujudkan KADARZI merupakan tujuan antara (intermediate goal). Hal ini berarti bahwa untuk meningkatkan keadaan gizi masyarakat, setiap upaya perbaikan gizi harus didukung dengan pendidikan/ penyuluhan gizi agar pengetahuan dan pemahaman keluarga tentang pentingnya gizi baik untuk hidup sehat meningkat. Diharapkan dengan meningkatnya pengetahuan keluarga tentang gizi dan kesehatan, tercipta pula keluarga yang mandiri dalam memperoleh zat-zat gizi yang diperlukan bagi seluruh anggota keluarga. Dengan demikian dalam memperoleh zat-zat gizi yang diperlukan, keluarga tidak tergantung pada keberadaan kegiatan program gizi.

Dalam konsep KADARZI, yang dimaksud dengan keluarga yang sadar gizi adalah keluarga yang mampu mengenali masalah gizi dan kesehatan anggota 
keluarganya serta mampu mengatasi atau mengupayakan bantuan untuk mengatasinya.

Untuk menunjang pencapaian KADARZI, perlu dilakukan reorientasi upaya perbaikan gizi yang telah ada dengan meningkatkan koordinasi dengan berbagai sektor terkait dan melibatkan masyarakat dalam proses pengkajian masalah, perencanaan program dan pemantauanevaluasi upaya program perbaikan gizi masyarakat. Dalam bukunya, Soekirman dkk MENUNJUK PENTINGNYA strategi pengembangan/peningkatan upaya pendidikan gizi bagi seluruh lapisan masyarakat dengan menggunakan teknologi komunikasi, informasi dan edukasi (KIE) yang tepat dalam upaya mencapai KADARZI sebagai tujuan antara dalam meningkatkan keadaan gizi masyarakat. Dalam hal ini penggalianpenggalian nilai-nilai sosial-budaya dalam masyarakat yang sangat bervariasi perlu ditingkatkan sehingga pesan-pesan pendidikan/penyuluhan gizi tidak mengalami benturan atau hambatan dalam penyampaiannya.

Dengan paradigma upaya perbaikan gizi yang mengarah pada KADARZI, maka perlu didukung oleh kegiatan-kegiatan penelitian dan pengembangan di bidang gizi ke arah tersebut. Oleh karena itu, peran Badan Penelitian dan Pengembangan Kesehatan ke depan dalam penggalian faktor-faktor sosial-budaya masyarakat yang sangat beragam bagi perumusan strategi pendidikan gizi untuk masyarakat menjadi sangat penting.

\section{KESIMPULAN}

Secara umum masalah gizi di Indonesia masih termasuk tinggi dan masih merupakan masalah kesehatan masyarakat (public health problem). Sampai saat ini upaya program gizi yang dilaksanakan masih belum secara optimal memberdayakan masyarakat dan belum secara optimal memanfaatkan potensi masyarakat yang ada.

Meningkatkan dan memperkuat koordinasi antar sektor dan melibatkan potensi yang ada di masyarakat dalam berbagai upaya perbaikan gizi masyarakat merupakan kunci penting bagi keberhasilan menuju KADARZI.

Paradigma upaya perbaikan gizi menuju KADARZI merupakan solusi yang tepat. Namun, perlu dukungan penelitian dan pengembangan, terutama dalam mengembangkan sarana pendidikan gizi bagi masyarakat yang sesuai dengan kondisi sosial-budaya masyarakat. Upaya mencapai KADARZI bukan saja ditujukan langsung kepada keluarga-keluarga, melainkan juga kepada pelaksana program pembangunan yang terkait dengan peningkatan kesejahteraan masyarakat.

\section{RUJUKAN}

1. BPS, Survei Demografi Kesehatan Indonesia, Jakarta, 1997.

2. Puslitbang Gizi Bogor, Survei gizi Indonesia Bagian Timur, Laporan Penelitian, 1990.

3. Puslitbang Gizi Bogor, Survei Vitamin A, Laporan Penelitian, 1992.

4. Departemen Kesehatan, Survei Kesehatan Rumah Tangga, Badan Litbangkes, 2001.

5. Strauss $\mathrm{J}$ et al. Indonesian living standards three years after the evidence from the Indonesia family life survey. 2003.

6. Direktorat Bina Gizi Masyarakat, Laporan survei evaluasi GAKI, Laporan Penelitian bekerja sama dengan Puslitbang Gizi dan Makanan, 2003.

7. Satoto. Hubungan antara kekurangan seng dengan tumbuh kembang anak. Majalah Penelitian Diponegoro 1996, 5(4): 231-236.

8. Penelitian skala kecil lainnya di Jawa Barat, Jawa Tengah dan Lombok (1997 -1999).

9. BPS, SUSENAS, Jakarta, 2002.

10. BPS-Statistics Indonesia. End of decade statistical report: data and descriptive analysis. Jakarta: BPS, 2000. 
11. Hartini TNS et al. Energy intake during economic crisis depends on initial wealth and access to rice fields: the case of pregnant Indonesian women. Health Policy 2002, 61(1): 57-71.

12. BPS-Statistics Indonesia, World Bank \& Ministry of Health. Report of household iodised salt consumption survey. Jakarta: BPS, 2002.

13. BPS \& UNICEF. Challenges for a new generation: the situation of children and women in Indonesia, 2000. Jakarta: BPS, 2000. p 69-70.

14. Horton S. Opportunities for investments in nutrition in low-income Asia. Asian Development Review 1999, 17(1,2): 246-273.

15. Husaini YK \& Husaini MA. Inputs for restructuring National Nutrition Program toward health paradigm, year 2010. Gizi Indonesia 2001, 25: 66-74.

16. Jahari $A B$ et al. Status gizi balita di Indonesia sebelum dan selama krisis: analisis data antropometri SUSENAS 1989-1999. Prosiding Widyakarya Nasional Pangan dan Gizi VII, 2000: 93 -123 \& 181-188.

17. Latief $\mathrm{D}$ et al. Family nutrition and under-five child health (FN-CH) programs in Indonesia: a review of the programs and their overall achievements, with recommendations for priority actions to reduce remaining gaps and disparities. Jakarta: Ministry of Health \& SEAMEO-Tropmed RCCN UI, 2000.
18. Mannar V. Consultation report on micronutrient in Indonesia. 2003.

19. Marchione T. Chapter 14. Overcoming malnutrition in a new era: conclusions and lessons. In: Marchione T (ed). Scaling up, scaling down: overcoming malnutrition in developing countries. Amsterdam: Gordon \& Breach, 1999.

20. Ministry of Health, Republic of Indonesia. National plan of action for food and nutrition, 2001-2005. Jakarta: Ministry of Health RI, 2000.

21. Morgan LM. Community participation in health: perpetual allure, persistent challenge. Health Policy and Planning 2001, 16(3): 221-230.

22. Soekirman, Atmarita, Jahari $A B$ \& Martianto D. Assessment of nutrition situation and conceptual framework for nutrition and public health interventions in Indonesia: emphasis on micronutrient deficiencies, 2004. Unpublished.

23. Soekirman et al. Economic growth, equity and nutritional improvement in Indonesia. Geneva: UN ACC/SCN, 1992.

24. Tabor SR, Dillon HS \& Sawit MH. Child growth, food insecurity and poverty in Indonesia. Paper prepared for 'International Expert Meeting on Child Growth', Jakarta, 10-13 November 2002.

25. UNICEF \& MI. Vitamin and mineral deficiency: a global damage assessment progress report. New York: UNICEF, 2004. 